ZOOLOGIA 28 (5): 565-570, October, 2011

doi: $10.1590 /$ S1984-46702011000500003

\title{
Oviposition and post-embryonic development of Aglaoctenus lagotis (Araneae: Lycosidae)
}

\author{
Vanessa Stefani Sul Moreira' \& Kleber Del-Claro, 2
}

\author{
${ }^{1}$ Laboratório de Ecologia Comportamental e de Interações, Instituto de Biologia, PPGECRN, Universidade Federal de \\ Uberlândia. 38400-902 Uberlândia, MG, Brazil. E-mail: vastefani@hotmail.com \\ ${ }^{2}$ Corresponding author. E-mail: delclaro@ufu.br
}

\begin{abstract}
The present study describes the life history of Aglaoctenus lagotis Holmberg, 1876 from oviposition to adulthood, analyzing the number of eggs in each egg sac, birth rate, number of instars, sex ratio, cephalothorax size of all instars, and developmental time in laboratory. The results indicate that the studied species can produce two egg sacs during the reproductive period, and that the post-embryonic phase includes 12 nymphal instars. A higher mortality rate was observed during the first three instars, featuring a Type III survival curve. The sex ratio was geared towards the female in the adults and no significant difference was observed in the length of the cephalothorax between male and female. This species can therefore be considered monomorphic. Sexual dimorphism was observed in the cuticle color, with males being light brown whereas females are dark brown.
\end{abstract}

KEY WORD. Birth rate; number of instars; sexual dimorphism.

The natural history of animals and plants still needs more scientific efforts to increase our true understanding about biodiversity and conservation (e.g. Del-claro \& TorezanSILINGARDI 2009). In life-history studies directed towards the conservation biology of invertebrates, basic data about the development of juvenile stages, life-tables, sexual maturity and reproductive success, are indicated as important characteristics to be investigated, especially in the Neotropics (SANTOS et al. 2007). Considering that immature spider are easy to identify, maintain under laboratory conditions and have their development studied, these arachnids are suggested as ideal models for life-history studies (Ahrens \& Kraus 2007). There are several examples of excellent laboratory studies from temperate regions which have successfully characterized spider lifecycles (Downes 1987, Alderweireldt \& DeKerr 1990, Wheeler et al. 1990); growth and development (WISE 1976); and life time (Nentwig 1990). Reproductive aspects, including sex-ratio, adaptation and reproductive success, and offspring survivorship are also issues of interest since the end of last century (Downes 1987, Alderweireldt \& Dekerr 1990, Wheeler et al. 1990). However, all these aspects are not well known or are simply ignored when tropical species are studied.

Lycosidae is one of the most abundant and diverse arachnid family with 2,374 known species (Platnick 2011). The individuals are generally very active on the surface of the soil and leaf litter of forests and fields where they hunt alone (WISE 1993). They usually present a stage of maternal care during reproduction when the egg sac and recently emerged individuals are transported and protected by the mother (GonZAGA 2007, STEFANI et al. 2011). Natural history studies are mostly related to habitat use, population densities in fragmented areas, and distribution patterns (Punzo 2003). Although there are studies focusing on the natural history of lycosid species such as Lycosa Latreille, 1804 (Miyashita 1969), Pardosa C.L. Kock, 1848 (Eason 1969, Buddle 2000), Hogna Simon, 1885 (Punzo 2003), and Pirata Sundevall, 1833 (Hendricks \& Maelfait 2003), even basic biological information is lacking for many species. Except for taxonomic studies (SANTOS \& BRESCOVIT 2001) and natural history descriptions of a few species (SteFAni et al. 2011), the knowledge about the general biology of Brazilian lycosids is still scarce.

Aglaoctenus Tullgren, 1905 belongs to the Sosippinae and is represented by South American spiders that build webs, an exception in Lycosidae (VIERA et al. 2007). Aglaoctenus lagotis Holmberg, 1876 builds a flat "capture sheet" from which a funnel shaped tube leads to its refuge (Riechert 1976). These spiders are common across Southeastern Brazil occurring both in forested areas and in savanna formations, extending to northern Argentina (SANTos \& BRESCOVIT 2001). Despite its abundance, this species is among the least known spiders in Brazil.

To fill this gap in existing information, this study presents qualitative and quantitative results on the biology of this species from oviposition to adulthood, including the number of eggs in each egg sac, birth rate, number of instars, main characteristics of each instar, sex ratio, quantification of the cephalothorax size, and the developmental time until adulthood. 


\section{MATERIAL AND METHODS}

During October 2007, 23 females carrying egg sacs (Fig. 1) were collected in the forest of the Parque Bosque John Kennedy(Araguari, Minas Gerais, Brazil; 48 $10^{\prime} 59^{\prime \prime} \mathrm{W}, 1^{\circ} 39^{\prime}$ $\left.02^{\prime \prime} \mathrm{S}\right)$. The park comprises a 11.2 ha area that is a fragment of a semi-deciduous seasonal forest with abundant presence of leaf matter, decaying trunks and twigs, and contains trees that are up to $25 \mathrm{~m}$ tall (SouZa \& Araújo 2005). All females were transported to the laboratory and kept individually in one liter plastic containers ( $14 \mathrm{~cm}$ in diameter $\mathrm{x} 10 \mathrm{~cm}$ in height) at a temperature of $26.7 \pm 4.2 \mathrm{C}^{\circ}$ and relative humidity of $62.4 \pm 9.5 \%$. Out of the 23 collected females, 13 were kept separately with their egg sacs in order to follow the development of the offspring to adulthood. The egg sacs from the remaining 10 females were removed to count the number of eggs. These 10 females produced a new egg sac which, was again removed for egg counting.

We considered as the first instar the young spiders emerging from the egg sac (which may, or may not, have molted inside the egg sac). First instar spiderlings were kept with the mother during the period of five days maternal care (STEFANI $e t$ al. 2011; Fig. 2) and subsequently individualized in $250 \mathrm{ml}$ plastic containers until the third instar. Beginning at the fourth instar the animals were stored in one liter plastic containers. The bottom of all plastic containers was covered with leaf matter substrate from the collection site. First to third instar spiderlings were fed three times a week, at the same time periods, with a larva of Palembus dermestoides Fairmaire, 1893 (Tenebrionidae), always smaller than the spider. Fourth and later instar spiderlings were fed with a $P$. dermestoides larva twice a week and once a week with Armithermes sp. termite workers $(\mathrm{N}=5)$. A cotton ball soaked in water was placed in the containers and replaced every three days.

All containers were checked daily from 08:00-12:00 h. The exuviae were removed from the container and stored dry in individually labeled envelopes for each spider. Each exuvia was placed between a slide and a cover slip in order to measure the cephalothorax in an optical microscope with an ocular containing a millimeter scale. The instar molting dates, were recorded for each reared individual, the number of survivors at each developmental stage was counted, and the sex ratio in the adult phase was calculated. All individuals that reached the adult phase were induced to mate with individuals born from different females.

The mean values of the studied variables were calculated and are shown in the format $\mathrm{X} \pm \mathrm{SD}$ (mean \pm standard deviation). The paired t-test was used with the data presenting a normal distribution to compare the quantity of eggs between the first and second egg sac produced by the spiders that had their egg sacs removed. The non-parametric Mann-Whitney U test was used for the comparison between the width of the cephalothorax of adult males and females because they did not present a normal distribution and did not reach normality even after transformation.
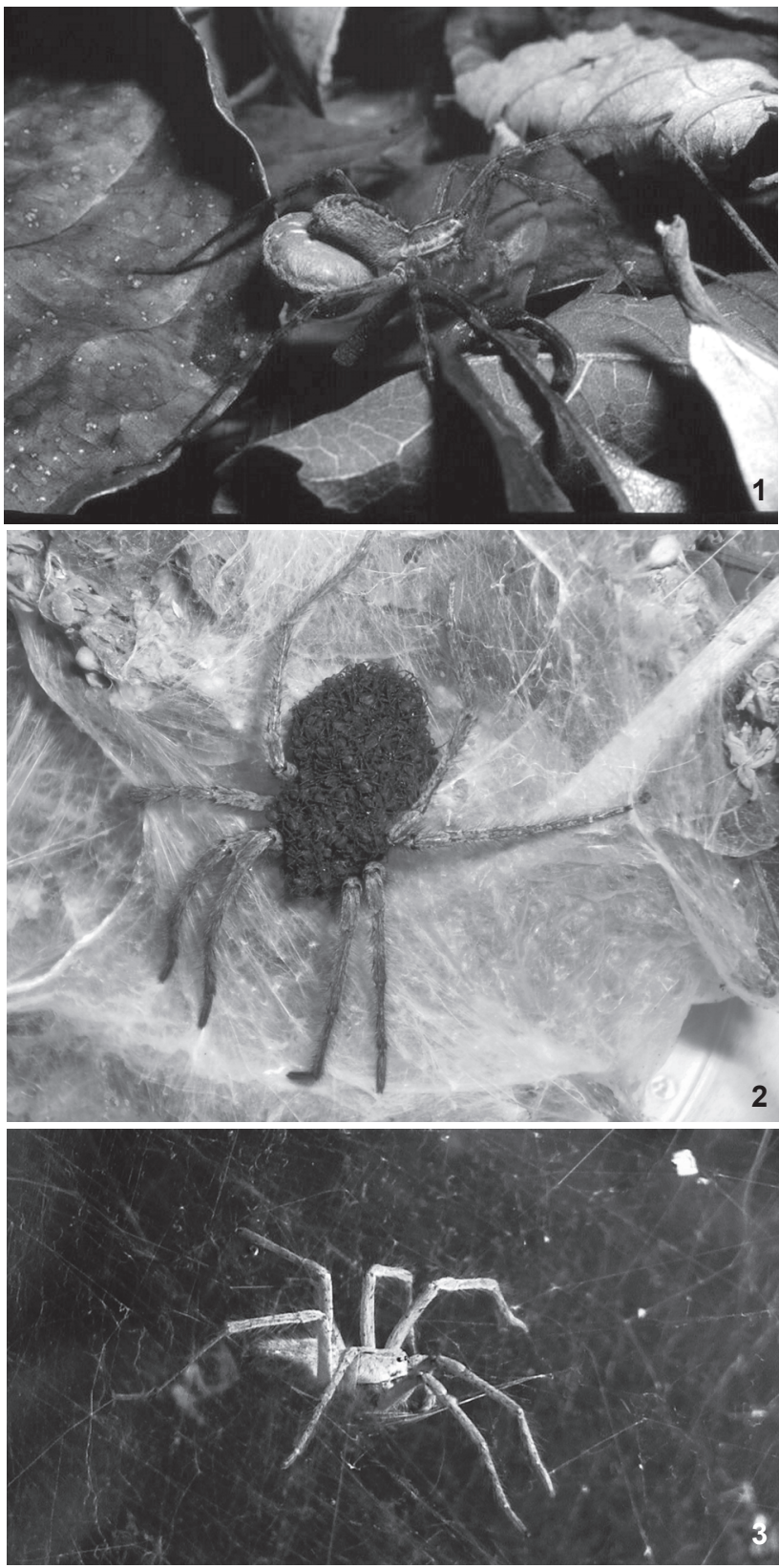

Figures 1-3. Female of Aglaoctenus lagotis (1) with egg sac; (2) spiderlings being transported by a female; (3) male with spermatic web between pedipalps.

The information obtained from the various stages of the A. lagotis life cycle were used to compile a life table. Thus, it was possible to list the total number of individuals in the population at each stage $\left(\mathrm{a}_{\mathrm{x}}\right)$ and calculate all table indexes (sensu Towsend et al. 2006) at the same time for: the proportion of the original cohort surviving at each time interval $\left(\mathrm{l}_{\mathrm{x}}=\mathrm{a}_{\mathrm{x}}-\mathrm{a}_{(\mathrm{x}+1)}\right)$, 
the proportion of the original cohort dying at each stage $\left(d_{x}=\right.$ $\left.1_{x}-\left(l_{x}+1\right)\right)$, and the mortality rate of each instar $\left(q_{x}=d_{x} / 1_{x}\right)$. The fecundity indices $\mathrm{F}_{\mathrm{x}}$ (total number of eggs produced at each stage, in this case represented by the last instar, single reproductive, $\mathrm{F}_{12}$ ), $\mathrm{m}_{\mathrm{x}}$ (birth rate or total number of eggs produced per female survivor, $\left.\mathrm{m}_{12}=\mathrm{F}_{12} / \mathrm{a}_{12}\right)$, and basic reproductive rate $\mathrm{R}_{\mathrm{x}}\left(\mathrm{R}_{12}=\Sigma \mathrm{F}_{12} / \mathrm{a}_{\mathrm{o}}\right)$, were also calculated.

\section{RESULTS}

With the ten A. lagotis egg sacs used to evaluate the number of eggs, the number of eggs in the first oviposition was significantly higher $(237.8 \pm 18.95$ eggs $)$ when compared to the second oviposition $(94.125 \pm 22.06$ eggs; $\mathrm{t}=8.7, \mathrm{p}<0.001)$.

All 13 egg sacs used to study the post-embryonic development produced spiderlings ( $\mathrm{N}=2,907$ young individuals). The average number of emerging individuals was $147.77 \pm 54.4$ individuals per egg sacs. The average time spent in each instar is shown in table I. In the last instar before adulthood, sexual dimorphism was already present in A. lagotis, being displayed in the males as the full development of copulatory bulbs and coloration showing light shades of brown differing greatly from the females which showed dark brown coloration. The sexual proportion indicated a deviation of the sex ratio toward females (4:3; females:males; from 47 adults, Tab. II). The average time spent in the adult phase was $100.45 \pm 24$ days $(\mathrm{N}=47$ individuals), with males living approximately 40 days less than females $(\mathrm{U}=2.76, \mathrm{p}=0.013)$. The average length of the cephalothorax in the first instar was $0.62 \pm 0.15 \mathrm{~mm}(\mathrm{~N}=1921$ individuals $)$, reaching $7.4 \pm 1.21 \mathrm{~mm}$ among adults $(\mathrm{N}=47$ individuals); males present smaller cephalothoraxes than females though the difference was not significant $(\mathrm{U}=19.0, \mathrm{p}=0.134$; Tab. I, Fig. 3).

Aglaoctenus lagotis adults reproduced in October and, although the total number of births $\left(\mathrm{a}_{0}\right)$ was $2,907(\mathrm{~N}=13 \mathrm{egg}$ sacs), only 47 juveniles reached maturity $\left(a_{12}\right)$ (Tab. II). Spiderlings emergence was $66 \%$ of all collected eggs representing a remarkable offspring survival rate in proportion to the original cohort size surviving over each time interval $\left(l_{x}\right)$. However, increased mortality occurs in the passage from the first to second instar, when the survival rate was only $8 \%$ (Tab. II), stabilizing in the following instars until adulthood presenting a Type III survival curve (sensu Towsend et al. 2006). Among the 47 surviving adults $\left(\mathrm{a}_{12}\right), 20$ were males and 27 females. All females maintained in the laboratory mated with non-related males (i.e., born from different egg sacs) and reproduced, producing a total of 6,426 eggs. Thus, the average number of eggs produced per female $\left(\mathrm{m}_{12}\right)$ was 238 and the net reproductive rate $(\mathrm{R})$ was 1.8 eggs per individual $(\mathrm{R}>1)$ (Tab. II).

\section{DISCUSSION}

The reproductive rate and the developmental pattern observed in A. lagotis is similar to those recorded in other
Table I. Characterization of the instars from birth to adulthood (instar 12), showing the average duration and the average size of the cephalothorax $(\mathrm{mm})$ for each development phase. Values shown as $X \pm S D$ (mean \pm standard deviation). For each instar, $N$ follows the same numbers as in Table II (see ax).

\begin{tabular}{lcc}
\hline \multicolumn{1}{c}{ Phases } & $\begin{array}{c}\text { Time } \\
\text { (days) }\end{array}$ & $\begin{array}{c}\text { Cephalothorax size } \\
(\mathrm{mm})\end{array}$ \\
\hline Egg & - & - \\
Instar 1 & $25.27 \pm 8.06$ & $0.62 \pm 0.150$ \\
Instar 2 & $21.45 \pm 3.35$ & $0.97 \pm 0.120$ \\
Instar 3 & $24.45 \pm 4.35$ & $1.35 \pm 0.170$ \\
Instar 4 & $24.54 \pm 5.37$ & $1.76 \pm 0.140$ \\
Instar 5 & $25.70 \pm 4.20$ & $2.00 \pm 0.100$ \\
Instar 6 & $27.00 \pm 5.20$ & $2.47 \pm 0.120$ \\
Instar 7 & $28.10 \pm 6.24$ & $3.02 \pm 0.042$ \\
Instar 8 & $29.50 \pm 4.50$ & $3.47 \pm 0.048$ \\
Instar 9 & $30.60 \pm 30.6$ & $3.82 \pm 0.120$ \\
Instar 10 & $34.58 \pm 50.0$ & $4.43 \pm 0.270$ \\
Instar 11 & $38.70 \pm 7.36$ & $5.54 \pm 0.400$ \\
Instar 12 (adult $=0^{\prime}+$ o) & $100.45 \pm 24.0$ & $7.40 \pm 1.210$ \\
Adult (only ơ) & $80.70 \pm 13.40$ & $6.97 \pm 0.500$ \\
Adult (only ) & $120.20 \pm 2.30$ & $8.60 \pm 0.740$ \\
\hline
\end{tabular}

Table II. Life table for the Aglaoctenus lagotis spider under captive conditions. The letters indicate: (ax) number of individuals present in each instar, (Ix) proportion of individuals surviving at each time interval, $(\mathrm{dx})$ mortality rate, $(\mathrm{Fx})$ total number of eggs produced by the females when reaching maturity, $(\mathrm{mx})$ individual fecundity, (Ro) basic reproductive rate, $(X)$ number of the instar (Egg = instar 0$)$.

\begin{tabular}{lrccccc}
\hline \multicolumn{1}{r}{ Stage } & \multicolumn{1}{c}{$\mathrm{ax}$} & $\mathrm{lx}$ & $\mathrm{dx}$ & $\mathrm{Fx}$ & $\mathrm{mx}$ & $\mathrm{Ro}$ \\
\hline Egg & 2907 & 1.0000 & 0.3400 & - & - & - \\
Instar 1 & 1921 & 0.6600 & 0.5800 & - & - & - \\
Instar 2 & 249 & 0.0800 & 0.0350 & - & - & - \\
Instar 3 & 133 & 0.0450 & 0.0080 & - & - & - \\
Instar 4 & 107 & 0.0370 & 0.0070 & - & - & - \\
Instar 5 & 85 & 0.0300 & 0.0070 & - & - & - \\
Instar 6 & 66 & 0.0230 & 0.0030 & - & - & - \\
Instar 7 & 58 & 0.0200 & 0.0020 & - & - & - \\
Instar 8 & 53 & 0.0180 & 0.0010 & - & - & - \\
Instar 9 & 50 & 0.0170 & 0.0002 & - & - & - \\
Instar 10 & 49 & 0.0168 & 0.0007 & - & - & - \\
Instar 11 & 47 & 0.0161 & 0.0000 & - & - & - \\
Instar 12 (adult) & $47^{*}$ & 0.0161 & & 6426 & 238 & 2.21 \\
\hline
\end{tabular}

*20 males and 27 females.

lycosids (Eason 1969, Buddle 2000, Brown et al. 2003, Hendricks $\&$ Maelfait 2003). The results on the reproductive biology and development of $A$. lagotis indicated that this spider is able to 
produce more than one egg sac during the reproductive period. The removal of the egg sacs induced a new production of egg sacs in all tested females. In the natural environment the strategy of additional egg production can represent an adaptive advantage as a reaction to predation and/or parasitism, even if the new oviposition produces fewer eggs. In a study by Brown et al. (2003) with Pirata sedentarius Montgomery, 1904, the females that had their egg sacs experimentally removed early in the reproductive season produced up to two more egg sacs, though a reduction in the number of eggs occurred sequentially. This reduction may be caused by a small quantity of spermatozoids being stored for an additional reproduction (Brown et al. 2003), as opposed to a reduction in resources as females were fed during the entire study. However, this does not occur under natural conditions, which may indicate the availability of food as a cause for the reduction in egg production (Ferguson \& Bohlen 1978, Nussbaum 1981, Brown et al. 2003).

The decrease in the number of eggs produced can also be a reflection of the cost of parental care (BeLL 1976). Monitoring the reproductive success of female of the harvestman Acutisoma proximum Mello-Leitão, 1922, in their natural environment, BuzATto et al. (2007) observed that when females were experimentally removed from their eggs, they had a higher probability $(0.41)$ to produce more eggs than the females that took care of their eggs (0.34). Aglaoctenus lagotis also offers maternal care to the offspring (protection and feeding) and this behavior was correlates directly correlated with the survival of the spiderlings until adulthood (Stefani et al. 2011).

The development time, the number of molts to maturity, and the size of the spiders are fundamental aspects to observe in the development of a protocol for breeding in captivity (Galiano 1967, Bernardo 1996, Marchioro et al. 2005). The mortality frequency is a significant aspect illustrating the importance of life tables. The survival rate of $66 \%$ between the egg stage and the first instar could be attributed to maternal care, since mothers fed their offspring with a yellowish substance released from their own oral cavity (Stefani et al. 2011). The highest mortality rate occurred between the first and second instar in A. lagotis, indicating a Type III survival curve, similar to the survival curves for populations of fish, insects and marine invertebrates, organisms which present higher mortality rate among youngsters (Towsend et al. 2006, Del-Claro \& Mound 1996). Prey was not always consumed in the initial stages, suggesting that mortality could have resulted from inefficient predation causing death by inanition. The food droplet released by the mother is consumed by the most agile and/or by the individuals near the female at that moment (Stefani et al. 2011). Mortality can be a result of natural causes (e.g. weaker individuals, physiological problems) and also due to diseases (SILVA et al. 2006). It is important to highlight that in natural environments several factors can exert an increase in the mortality of spider populations: climatic aspects (for example, reproduction in the rainy season with the presence of storms), food availability, predation, parasitism, intra and inter specific competition, cannibalism, availability of sites for webs and other structural aspects of the habitat (RIECHERT 1974, RieCHERT \& TRACY 1975, Riechert \& Lockley 1984, Oxford 1993). Furthermore, cannibalism among arachnids is common when food is restricted (Rypstra 1983, Tizo-Pedroso \& Del-Claro 2011).

The number of instars recorded in A. lagotis was 12 while in other lycosids, including Lycosa (Mirashita 1969), Pirata (BRown et al. 2003, Hendricks \& Maelfatt 2003), Pardosa (Eason 1969, Buddle 2000) and Schizocosa Chamberlin, 1904 (Dondale 1961, Whiтcomb 1967) the number observed was between seven and ten instars. According to Punzo (1991), the nutritional level and the environment temperature may influence juvenile development. Thus, variations in laboratory conditions may cause variation in developmental times. VerTAINen et al. (2000) showed that females of the lycosid Hygrolycosa rubrofasciata Ohlert, 1865 which received less food presented lower growth rates, longer development time and a greater number of instars until maturity, and became adults at smaller sizes than those who received more food.

In the present study, A. lagotis presented a biased sex ratio toward females. Vollrath \& PARKer (1992) found similar results for the lycosid Pardosa milvina Hentz, 1844. For the lycosids in this study, no significant difference in cephalothorax length between males and females reared in the laboratory was observed. However, the sexual dimorphism observed in the coloration established a clear distinction between the sexes in $A$. lagotis with males possessing a light brown color and females a dark brown color. This distinction is useful in the field where the sexual identification and differentiation must be made with necessary accuracy and speed (e.g. Almeida et al. 2000).

This study is the first to detail the reproductive biology and development of common Brazilian lycosid. However, the results from biological studies executed in the laboratory must be used with caution when making assumptions about the real biology of a species.

\section{ACKNOWLEDGEMENTS}

We are thankful to the municipality of Araguari for permission to carry out this work in the Parque Bosque John Kennedy. We thank Rodrigo H. Willermart, Pedro Gnaspini and two anonymous reviewers for valuable suggestions of the manuscript. Kleber Del Claro is thankful to the CNPq (PQ research grant).

\section{LITERATURE CITED}

Ahrens, L. \& J.M. Kraus. 2007. Wolf spider (Araneae, Lycosidae) movement along a pond edge. Journal of Arachnology 34: $532-539$.

Alderweireldt, M. \& R. Dekerr. 1990. Field and laboratory observation on the life cycle of Pachygnatha degeeri Sundevall, 1830 and Pachygnatha clercki Sundervall, 1823 (Araneae, Tetragnathidae). Acta Zoologica Fennica 190: 35-39. 
Almeida, C.E.; E.F. Ramo; E. Gouvea; M. Carmo-Silva \& M. Costa. 2000. Natural history of Ctenus medius Keyserling, 1891 (Araneae, Ctenidae): observations on habitats and the development of chromatic patterns. Brazilian Journal of Biology 60: 503-509.

Bell, G. 1976. On breeding more than once. American Naturalist 110: 57-77.

Bernardo, J. 1996. The particular maternal effect of propagule size, especially egg size: patterns, models, quality of evidence and interpretations. American Zoologist 36: 216-236.

Brown, C.A.; B.M. SANFord \& R.R. Swedon. 2003. Clutch size and offspring size in the wolf spider Pirata sedentarius (Araneae, Lycosidae). Journal of Aracnology 31: 285-296.

Buddle, C.M. 2000. Life history of Pardosa moesta and Pardosa mackenziana (Araneae: Lycosidae) in Central Alberta, Canada. Journal of Arachnology 28: 319-328.

Buzatto, B.A.; G.S. Requena; E.G. Martins \& G. Machado. 2007. Effects of maternal care on the lifetime reproductive success of females in a neotropical harvestman. Journal of Animal Ecology 76: 937-945.

Del-Claro, K. \& H.M. Torezan-Silingardi. 2009. Insect-Plant interactions: new pathways to a better comprehension of ecological communities in neotropical savannas. Neotropical Entomology 38: 159-164.

Del-Claro, K. \& L.A. Mound. 1996. Phenology and description of a new species of Liothrips (Thysanoptera: Phlaeothripidae) from Didymopanax (Araliaceae) in Brazilian cerrado. Revista de Biologia Tropical 44: 193-197.

Dondale, C. D. 1961. Life histories and habits of some common spiders from trees and shrubs in Nova Scotia. Canadian Journal Zoology 39: 777-787.

Downes, M.F. 1987. Postembryonic development of Latrodectus hasselti Thorell (Araneae, Theridiidae). Journal of Arachnology 14: 293-301.

EAsON, R.R. 1969. Life history and behavior of Pardosa lapidicina Emerton (Araneae: Lycosidae). Journal of the Kansas Entomological Society 42: 339-360.

Ferguson, G.W. \& C.H. Bohlen. 1978. Demographic analysis: a tool for the study of natural selection of behavioral traits, p. 227-243. In: N. Greenberg \& P. MacLean (Eds). Conference on Behavior and Neurology of lizards. Washington, DC, Dhew Publication, 491p.

Galiano, M.E. 1967. Ciclo biológico e desarollo de Loxosceles laeta (Nicolet, 1849). Acta Zoologica Lilloana 23: 431-464.

Gonzaga, M.O. 2007. Socialidade e cuidado, p. 185-208. In: M.O. Gonzaga, A.J. SAntos, H.F. JaPYASSú (Eds). Ecologia e Comportamento de Aranhas. São Paulo, Editora Interciências, 400p.

Hendricks, F. \& J. Maelfait. 2003. Life cycle, reproductive patterns and their year-to-year variation in a field population of the wolf spider Pirata piraticus (Araneae: Lycosidae). Journal of Arachnology 31: 331-339.

Marchioro, C.A.; M.L. Fisher \& E.M. Silva. 2005. Desenvolvimento pós-embrionário de Loxosceles intermedia Mello-Lei- tão, 1934, L. laeta Nicolet, 1849 e L. gaucho Gertsch, 1967 (Araneae: Sicariidae) criadas sob condições de Alimentação monoespecífica. Biotemas 18: 93-112.

MiYAshitA, K. 1969. Seasonal changes of population density and some characteristics of overwintering nymphs of Lycosa $t$ insignita (Araneae: Lycosidae). Applied Entomology and Zoology 4: 1-8.

Nentwig, W. 1990. A zigomycetous fungus as a mortality factor in a laboratory stock of spiders. Journal of Arachnology 18: $118-121$.

Nussbaum, R.A. 1981. Seasonal shifts in clutch-size and egg-size in the side-blotched lizard, Uta stansburiana Baird and Girard. Oecologia 49: 8-13.

OXFoRD, G.S. 1993. Components of variation in population in population size in the spider Enoplognatha ovata (Clerk) sensu stricto (Araneae: Theridiidae). Bulletin of the British Arachnological Society 9: 193-202.

Platnick, N.I. 2011. The world spiders catalog. version 11.5 By The American Museum of Natural History. Available online at: http://research.amnh.org/iz/spiders/catalog [Accessed: 02/I/2011].

Punzo, F. 1991. The effects of temperature and moisture on survival capacity, cuticular permeability, hemolymph osmoregulation, and metabolism in Centruoides hentzi (Banks) (Scorpiones,Buthidae). Comparative Biochemistry and Physiology 100: 833-837.

Punzo, F. 2003. Observations on the natural history and ecology of the wolf spider, Hogna carolinensis Walckenaer (Araneae: Lycosidae) in the northern Chihuahuan Desert. Bulletin of the British Arachnological Society 12: 399-405.

RIECHERT, S.E. 1974. Thoughts on the ecological significance of spiders. BioScience 24: 352-356.

Riechert, S.E. 1976. Web-site selection in the desert spider Agelenopsis aperta. Oikos 27: 311-315.

Riechert, S.E. \& T. Lockley. 1984. Spiders as biological control agents. Annual Review of Entomology 29: 299-320.

RiecherT, S.E. \& C.R. Tracy. 1975. Thermal balance and prey availability: bases for a model relating web-site characteristics to spider reproductive success. Ecology 56: 265-284.

RYPSTRA, A.L. 1983. The importance of food and space in limiting web-spider densities; a test using field enclosures. Oecologia (Berlin) 59: 312-316.

Santos, A.J. \& A.D. Brescovit. 2001. A revision of the South American spider genus Aglaoctenus Tullgren, 1905 (Araneae, Lycosidae, Sosippinae). Andrias 15: 75-90.

Santos, A.J.; A.D. Brescovit \& H.F. Japyassú. 2007. Influência da estrutura do habitat na abundância e diversidade de aranhas, p. 25-44. In: M.O. GonZAGA; A.J. SANTOS \& H.F. JAPYAssú (Eds). Ecologia e Comportamento de Aranhas. São Paulo, Editora Interciências, 400p.

Silva, M.L.C.; P.F. Martinez; N.I. Izeli; I.R. Silva; A.F.D. Vasconcelos; M.S.Cardoso; R.M. Stelutti; E.C. Giese \& A.M. Barbosa. 2006. Caracterização química de glucanas fúngicas e suas 
aplicações biotecnológicas. Química Nova 29: 85-92.

Souza JP. \& G.M. ARAúJo. 2005. Estrutura arbustivo/arbórea do subosque de clareiras e áreas sob dossel fechado em floresta estacional semidecidual urbana em Araguari - MG. Journal of Biociences 21: 93-102.

Stefani, V.; K. Del-Claro; L.A. Silva; B. Guimarães \& E. Tizo-Pedroso. 2011. Mating behaviour and maternal care in the tropical savanna funnel-web spider Aglaoctenus lagotis Holmberg (Araneae: Lycosidae). Journal of Natural History 45: 11191129.

Tizo-Pedroso, E. \& K. Del-Claro. 2011. Is there division of labor in cooperative pseudoscorpions? An analysis of the behavioral repertoire of a tropical species. Etology 117: 498507.

Townsend, C.L.; M. Begon \& J.L. Harper. 2006. Fundamentos em Ecologia. Porto Alegre, Artmed, $2^{\text {nd }}$ ed., 592p.

Vertainen, L.; R.V. Alatalo; J. Mappes \& S. Parri. 2000. Sexual differences in growth strategies of the wolf spider Hygrolycosa rubrofasciata. Evolutionary Ecology 14: 595-610.
Viera, C.; H.F. Japyassú; A.J. Santos \& M.O. Gonzaga. 2007. Teias e forrageamento, p. 45-66. In: M.O. GonZAGa; A.J. SANTOS \& H.F. JAPYASSÚ (Eds). Ecologia e Comportamento de Aranhas. São Paulo, Editora Interciências, 400p.

Vollrath, F. \& G.A. Parker. 1992. Sexual dimorphism and distorted sex-ratios in spiders. Nature 360: 156-159.

Wheeler, G.S.; J.P. McCafrey \& J.B. Johnson. 1990. Developmental biology of Dictyna spp. (Araneae: Dictynidae) in the laboratory and field. American Midland Naturalist 123: 124-134.

Wнітсомв, W.H. 1967. Wolf and lynx spider life histories. Fayetteville, University of Arkansas, Department of Entomology, Terminal Report for National Science Foundation, p. 35-39, p. 42-56.

WISE, D.H. 1976. Variable rates of maturation of the spider Neriene radiate (Lyniphia marginata). American Midland Naturalist 96: 66-75.

Wise, D.H. 1993. Spiders in ecological webs. Cambridge, Cambridge University Press, 328p.

Submitted: 20.IV.2011; Accepted: 25.VIII.2011.

Editorial responsibility: Pedro Gnaspini 